\title{
Improving Service Quality towards Consumer Satisfaction on Gojek Transportation Services Using the Importance Perfomance Analysis (IPA) Method
}

\author{
Paris Johannes Ginting ${ }^{1}$, Fendi Wijaya ${ }^{2}$, Calvin Jung ${ }^{3}$ \\ ${ }^{1,2,3}$ Universitas Prima Indonesia \\ yoghiell@yahoo.com
}

\begin{abstract}
Gojek is a social-minded company that is leading the online-based transportation industry revolution that can be accessed through an application on a smartphone. Gojek also provides various other services such as GoRide, GoCar, GoFood, GoMart, GoBox, and GoSend. There are various kinds of services provided by Gojek which are expected to be able to maintain and improve service quality. The purpose of this study was to determine the level of satisfaction of Universitas Prima Indonesia students with gojek online transportation services. This type of research is a research using survey method. The minimum number of samples that must be taken is 60 people so that the sample can represent the total population. This research uses importance performance analysis (IPA). Importance performance analysis (IPA) is a method used to measure the level of service satisfaction that is included in the quadrants on the importance performance matrix map. The results of the study show that the service quality and facilities provided by Gojek exceed the expected expectations and are sufficient to consumer satisfaction hearts because the services provided by Gojek can be carried out well by Gojek drivers to consumers and the application made by Gojek is very easy to use.
\end{abstract}

Keywords

service quality; facilities; consumer satisfaction; gojek

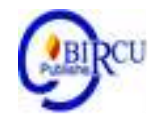

\section{Introduction}

Along with the development of an increasingly rapid technological era and progress in education and a more prosperous economy, changes in the socio-cultural culture of the community, as well as the development of advanced science and technology, transportation and communication facilities are also becoming easier so as to make human activities faster and more practical. In the modern era like today, means of transportation and communication cannot be separated from human life. Because these two things are often used to facilitate all human work.

People are getting more creative and innovative every day creating new businesses, especially businesses that provide online transportation services. Because humans today need transportation that is fast, convenient, safe and easy to find. In urban areas such as the city of Medan, which is quite large and has a dense population, congestion often occurs and many people use private vehicles, which triggers the congestion. To answer the needs of the community, currently an online transportation application provider company has been born. An example is Gojek. Gojek is a company that was first established in the city of Jakarta in 2011.

Gojek is a social-minded company that is leading the online-based transportation industry revolution that can be accessed through an application on a smartphone. Gojek also provides various other services such as GoRide, GoCar, GoFood, GoMart, GoBox, and 
GoSend. There are various kinds of services provided by Gojek which are expected to be able to maintain and improve the quality of their services. The purpose of this study was to determine the level of satisfaction of Universitas Prima Indonesia students with gojek online transportation services.

Due to the effectiveness of this company's goal of partnering with experienced motorcycle taxi drivers and increasing customer interest, Gojek has been developed in other big cities such as the JaBoDeTaBek area, Bandung, Medan, Surabaya, Bali and other cities.

The presence of gojek in Medan city on November 15, 2015, since the presence of gojek in Medan City will become an alternative tool for people to travel. Its head office is located at Komplek Jati Junction Jalan Perintis Kemerdekaan (near Universitas Nomensen).

For now, Gojek is no stranger to the public, especially the Medan City, so this service provider wants to make its customers feel comfortable and satisfied. If consumers are satisfied and comfortable, then they will use this service repeatedly until they can become loyal customers so that the Gojek company becomes the market leader and this company becomes an advanced company and is trusted by customers in Indonesia.

Competition between online transportation is getting tighter after several other online transportation services such as Grab, In-Driver, Uber, and Maxim appeared. The existence of this competition, it is necessary to analyze the satisfaction of users of Gojek transportation services.

\section{Review of Literature}

\subsection{Definition of Transportation}

The definition of transportation proposed by Nasution (1996) is defined as the transfer of goods and people from the place of origin to the destination. So with these activities, there are three things, namely the presence of cargo being transported, the availability of vehicles as a means of transportation, and the presence of roads that can be passed. The process of moving from the movement to the place of origin, where the transportation activity begins and to the destination where the activity ends. For this reason, with the transfer of goods and people, transportation is one of the sectors that can support economic activity (the promoting sector) and service providers (the servicing sector) for economic development. Another understanding is put forward by Soesilo (1999) who argues that transportation is the movement of people's behavior in space both in carrying themselves and carrying goods.

Transportation at this time has become a basic need for community activities, especially the activities of the people of North Sumatra. These activities make transportation an important choice with an increasing number of populations using transportation modes, especially public transportation. In the course of transportation, it is really needed an affective policy and management. We often hear this management in terms of Traffic Management and Mode of Transportation. Traffic management includes the Planning, Arrangement, Supervision and Control Processes. (Agussani, 2020)

In addition, Tamin (1997:5) reveals that transportation infrastructure has as a tool to direct development in urban areas; and as an infrastructure for the movement of people and/or goods arising from activities in the urban area. By looking at the two roles described above, the first role is often used by regional development planners to be able to develop their territory according to the plan. For example, a new area will be developed where there will never be a demand for it if the area is not provided with a transportation infrastructure system. So in these conditions, transportation facilities will be important for accessibility to the area and will have an impact on the high interest of the community to carry out economic 
activities. This is an explanation of the second role of transportation infrastructure, namely to support the movement of people and goods.

Economic activities and transportation have a very close relationship, where both can influence each other. This is as stated by Tamin (1997:4) that economic growth is related to transportation, because as a result of economic growth, a person's mobility increases and the need for movement increases beyond the capacity of available transportation infrastructure. It can be concluded that transportation and the economy are closely related.

On the one hand, transportation can encourage an increase in the economic activity of a region, because with the transportation infrastructure, an area can increase its economic activity. But on the other hand, due to high economic activity where economic growth increases, transportation problems will arise, due to traffic congestion, so it is necessary to add transportation routes to compensate for the high economic activity. The importance of the role of the transportation sector for economic activities requires the existence of a transportation system that is reliable, efficient, and effective. Effective transportation means that a transportation system that fulfills the carrying capacity, is integrated or integrated with inter-mode transportation, is orderly, organized, smooth, fast and precise, safe, secure, comfortable and economically affordable. While efficient in the sense that the public burden as a user of transportation services is low and has high utility.

\subsection{Transportation Benefits}

According to Soesilo (1997) transportation has enormous benefits in overcoming the problems of a city or region. Some of the benefits that can be delivered are:

1. Operating Cost Saving

These savings will be greatly felt for companies that use transportation means, such as buses and trucks. Savings arise because the condition of transportation facilities is getting better and the amount varies according to the type of vehicle and the condition of the facilities. In the case of road transportation, the savings are calculated for each type of vehicle per $\mathrm{km}$, as well as for certain types of roads and at certain levels of speed.

The costs that can be calculated for vehicle operation are as follows:

1) The use of fuel, which is influenced by the type of vehicle, speed, the ups and downs of the road, bends and the type of road surface.

2) Use of lubricants;

3) Use of tires;

4) spare parts maintenance;

5) Depreciation and interest;

6) Driver time and passenger time.

2. Time Saving

Another important benefit of a transportation project is the time savings for passengers and goods. For passengers, the time savings can be attributed to the many other jobs that passengers can do. The benefits of saving time can be calculated by multiplying the difference in travel time by the average hourly income of the number of workers who use the facility. The time-saving benefits for goods are mainly seen in goods that quickly decline in value if they do not reach the market immediately, such as vegetables, fruits and fish. Another benefit due to the savings in travel time is the cost of capital (capital on working capital) in connection with the procurement of supplies.

3. Reduction of accidents For certain projects, reduction of accidents is a real benefit of the existence of transportation. Such as improvements to shipping transportation facilities, railroads and so on have been able to reduce accidents. However, in Indonesia, this problem still has not received much attention, making it difficult to estimate the magnitude 
of the benefits due to reduced accident costs. If accidents increase with an increase in transportation facilities and infrastructure, this becomes an additional cost or negative benefit.

4. Benefits due to economic development In general, transportation activities will have an impact on the economic activities of a region. The magnitude of this benefit is highly dependent on the elasticity of production to transportation costs. The additional output from these production activities with the presence of roads minus the value of production facilities is a benefit of the project.

5. Indirect benefits It is a benefit that is obtained because of the connection of an area with other areas through transportation routes. In addition to the benefits due to the integration of the two regions, there will be an even distribution of income and prestige, so this benefit is very difficult to calculate quantitatively.

\subsection{Importance-Performance Analysis (IPA)}

The importance-performance analysis (IPA) technique was first proposed by Martilla and James, which was also introduced by Magal and Levenburg. In this technique, respondents are asked to rate the importance of various relevant attributes and the level of company performance (perceived performance) on each of these attributes. Then the average value of the importance of attributes and company performance will be analyzed in importance performance (Martilla and James, 1997).

IPA can also be interpreted as a tool in analyzing or used to compare to what extent the performance/service perceived by consumers is compared to the desired level of satisfaction. The level of conformity is the result of a comparison between the implementation performance score and the interest score, so that this level of conformity will determine the priority scale that will be used in handling factors that affect consumer satisfaction (Lupiyoadi dan Bramulya, 2015).

IPA unites the measurement of the performance level factor which is then depicted in a two-dimensional diagram, namely the importance-performance diagram to obtain practical suggestions and facilitate data explanation. Measurement of customer satisfaction according to Kotler and Keller in knowing customer satisfaction or dissatisfaction can be done through this method.

IPA is described in the form of a cartesian diagram, which is a shape divided into four quadrants bounded by two lines that intersect perpendicular to the point $(\mathrm{X}, \mathrm{Y})$ where $\mathrm{X}$ is the average score of the perceived performance or service assessment and $\mathrm{Y}$ is the average score of the assessment of interest/expectations that meet customer satisfaction. It is used to determine the position of each attribute or measure of service quality with the level of importance for the quality of service provided. follows:

The division on the Cartesian diagram of Importance Performance analysis is as

a. Quadrant A, Top Priority

Factors located in this quadrant are considered as very important factors by consumers.

However, the current conditions are not satisfactory, so the management is obliged to allocate adequate resources to improve the performance of these various factors. Factors located in this quadrant are a priority to be improved.

b. Quadrant B, Maintain Achievement

Factors located in this quadrant are considered as supporting factors for customer satisfaction so that the management is obliged to ensure that the performance of the institution it manages can continue to maintain the achievements that have been achieved.

c. Quadrant C, Low Priority 
Factors located in this quadrant have a low level of satisfaction and at the same time are considered not too important for consumers, so management does not need to prioritize or pay too much attention to these factors.

d. Quadrant D, Redundant

Factors located in this quadrant are considered not very important so that management needs to allocate resources related to these factors to other factors that have higher priority for handling which still need improvement.

\subsection{Purpose of Importance-Performance Analysis (IPA)}

Importance-performance analysis (IPA) aims to display information related to service factors that according to customers greatly affect their loyalty and satisfaction, and service are not satisfactory to customers. IPA unites the measurement of performance and importance factors which are then described in a two-dimensional diagram, namely the Importance Performance diagram to obtain practical suggestions and facilitate data explanation.

\section{Research Methods}

This type of research is a research using survey method. Survey research is research that takes a sample from one population and uses a questionnaire as the main data collection tool (Siregar, 2013). The survey method aims to obtain information on the number of respondents who are considered representative of the population in Industrial Engineering and Informatics Engineering, Universitas Prima Indonesia.

This research was conducted at the Industrial Engineering and Informatics Engineering, Universitas Prima Indonesia and was carried out from October to November 2020. The object of this journal's research is the service quality of Gojek transportation services to the consumer satisfaction of Industrial Engineering and Informatics Engineering students. Three components of total service quality. According to Gronroos in Tjiptono (2004), namely technical quality, functional quality, and corporate image. Each of these dimensions is translated into several attribute questions that have been adjusted to the quality of service to customer satisfaction.

According to Sugiyono (2017:137) the sample is part of the number of characteristics possessed by the population. The sample is part of the existing population, so that sampling must use a certain method based on existing considerations. The minimum number of samples that must be taken is 60 people so that the sample can represent the total population. This research uses importance performance analysis (IPA). Importance performance analysis (IPA) is a method used to measure the level of service satisfaction that is included in the quadrants on the importance performance matrix map (Dirgantara and Sumbodo, 2015).

\section{Result and Discussion}

\subsection{Gojek Profile}

Gojek (previously written as GO-JEK) is a technology company from Indonesia that serves transportation via motorcycle taxi services. The company was founded in 2010 in Jakarta by Nadiem Makarim. Currently, Gojek is available in 50 cities in Indonesia. As of June 2016, the Gojek application has been downloaded nearly 10 million times on Google Play on the Android operating system, and is available on the App Store. Gojek also has a digital payment service called Gopay. Apart from Indonesia, Gojek services are now available in Thailand, Vietnam and Singapore. 
On May 17, 2021, Tokopedia and Gojek officially announced the merger and formed the GoTo Group. The name GoTo itself comes from the abbreviations of Gojek and Tokopedia and also comes from the word mutual cooperation (Gojek, 2021).

\subsection{Customer Satisfaction Index (CSI)}

Customer satisfaction index (CSI) is WT divided by the max value of the likers scale used, then multiplied by $100 \%$. The level of satisfaction of respondents as a whole can be seen from the criteria for the level of satisfaction as follows:

Customer Satisfaction Index $(\mathrm{CSI})=\frac{\text { wT }}{\text { Likert scale max value }} \times 100 \%$

Customer Satisfaction Index $(\mathrm{CSI})=\frac{313.04}{5} \times 100 \%$

Customer Satisfaction Index $(\mathrm{CSI})=62.61 \%$

After getting the CSI value, it can be concluded that the CSI criteria are in the Table below:

Table 1. CSI Criteria

\begin{tabular}{|c|c|}
\hline Index Value (\%) & Customer Satisfaction Index (CSI) Criteria \\
\hline $81.00-100.00$ & Very Satisfied \\
\hline $66.00-80.99$ & Satisfied \\
\hline $51.00-65.99$ & Quite Satisfied \\
\hline $35.00-50.99$ & Less Satisfied \\
\hline $0.00-34.99$ & Not Satisfied \\
\hline
\end{tabular}

In this study, the service quality and facilities provided by Gojek which were examined using the customer satisfaction index (CSI) method obtained an index value of $62.61 \%$ which was categorized as quite satisfied.

\subsection{Importance-Performance Analysis (IPA)}

Then analyzed using the importance-performance analysis (IPA) method to get a total respondent level of suitability value of $86.72 \%$, so from the 17 questions made there are only 7 questions that get a value of $<86.72 \%$.

The value of the total respondent's level of conformity (Total Tki) between $\mathrm{X}$ (perception) and $\mathrm{Y}$ (expectation):

Is known:

$\Sigma \mathrm{Xi}=3468$

$\Sigma \mathrm{Yi}=3999$

Tki Total $=\frac{3468}{3999} \times 100 \%$

Tki Total $=86.72 \%$

After getting the Total Tki value $=86.72 \%$, then the value $<86.72 \%$ is concluded in the Table below: 
Table 2. Tki Suitability Level

\begin{tabular}{|c|c|c|c|c|c|}
\hline $\mathrm{X} 2$ & 272 & Y2 & 236 & Tk2 & $115,25 \%$ \\
\hline $\mathrm{X} 3$ & 252 & Y3 & 237 & Tk3 & $106,33 \%$ \\
\hline$X 4$ & 249 & Y4 & 240 & Tk4 & $103,75 \%$ \\
\hline$\times 5$ & 228 & Y5 & 234 & Tk5 & $97,44 \%$ \\
\hline $\mathrm{X} 6$ & 231 & Y6 & 214 & Tk6 & $107,94 \%$ \\
\hline $\mathrm{X7}$ & 224 & Y7 & 253 & Tk7 & $88,54 \%$ \\
\hline $\mathrm{x} 8$ & 227 & Y8 & 233 & Tk8 & $97,42 \%$ \\
\hline $\mathrm{X9}$ & 195 & Y9 & 214 & Tk9 & $91,12 \%$ \\
\hline $\mathrm{X} 10$ & 248 & $\mathrm{Y} 10$ & 236 & Tk10 & $105,08 \%$ \\
\hline $\mathrm{X} 11$ & 216 & Y11 & 250 & Tk11 & $86,40 \%$ \\
\hline $\mathrm{X} 12$ & 152 & $\mathrm{Y} 12$ & 228 & Tk12 & $66,67 \%$ \\
\hline $\mathrm{X} 13$ & 218 & Y13 & 197 & Tk13 & $110,66 \%$ \\
\hline $\mathrm{X} 16$ & 138 & Y16 & 212 & Tk16 & $65,09 \%$ \\
\hline $\mathrm{X} 17$ & 159 & Y17 & 201 & Tk17 & $79,10 \%$ \\
\hline $\mathrm{X} 18$ & 149 & Y18 & 285 & Tk18 & $52,28 \%$ \\
\hline $\mathrm{X} 19$ & 170 & $\mathrm{Y} 19$ & 273 & Tk19 & $62,27 \%$ \\
\hline$\times 20$ & 140 & $\mathrm{Y} 20$ & 256 & Tk20 & $54,69 \%$ \\
\hline$\sum x i$ & 3468 & $\sum Y \mathrm{i}$ & 3999 & & \\
\hline
\end{tabular}

The results of the study show that the service quality and facilities provided by Gojek exceed the expected expectations and are sufficient to consumer satisfaction hearts because the services provided by Gojek can be carried out well by Gojek drivers to consumers and the application made by Gojek is very easy to use.

\section{Conclusion}

The results of the study show that the service quality and facilities provided by Gojek exceed the expected expectations and are sufficient to consumer satisfaction hearts because the services provided by Gojek can be carried out well by Gojek drivers to consumers and the application made by Gojek is very easy to use.

Researchers suggest that Gojek's facilities and services provided to consumers are satisfactory, so that innovations, facilities, and services provided to consumers can be improved so that they can still compete with other competitors

\section{References}

Agussani. (2020). Implementation Analysis of Trans Mebidang Program in Transportation Mode Services, North Sumatera (Comperative Study of Medan City). Budapest International Research and Critics Institute-Journal (BIRCI-Journal). P. 1167-1174

Dirgantara, H., \& Sumbodo, A. (2015). Penerapan Model Importance Performance Analysis dalam Study Kasus: Analisis Kepuasan Konsumenbhinneka.com. Jakarta.

Gojek. (2021). About Gojek. Accessed from https://www.gojek.com/id-id/about/, on June 22, 2021.

Lupiyoadi, Rambat \& Bramulya. (2015). Model Important Performance Analysis. Jakarta: Salemba Empat.

Martilla \& James. (1997). Important Performance Analysis. Journal of Marketing, 41:13-17. Nasution. (1996). Manajemen Transportasi. Jakarta: Ghalia Indonesia. 
Siregar, Syofian. (2013). Metode Penelitian Kuantitatif. Jakarta: PT Fajar.

Soesilo, Nining I. (1999). Ekonomi, Perencanaan dan Manajemen Kota. Magister Perencanaan dan Kebijakan Publik. Jakarta: Universitas Indonesia.

Sugiyono. (2017). Metode Penelitian Kuantitatif, Kualitatif, dan R \& D. Bandung: CV Alfabeta.

Tamin, O. Z. (1997). Perencanaan dan Pemodelan Transportasi. Teknik Sipil, Institut Teknologi Bandung.

Tjiptono, Fandy. (2004). Strategi Pemasaran. Edisi Kedua. Cetakan Keenam. Yogyakarta: Penerbit Andy. 